According to the present investigation, the formation of ridges in a feather follows, and is probably due to, the rapid proliferation of intermediate cells causing increased pressure on the pulp, while lateral expansion is prevented by the sheath. These ridges proceed in a curve round the feather germ, so that ultimately the ridge nearest the ventral point lies dorsally. There is no suggestion of a movement of cells from one position to the other-rather a passive cutting up of the intermediate cell layer.

The rhachis has a complex origin, as Davies and Strong agree, but which Lillie and Juhn consider incorrect. Sections through the tip of a feather show a ring of barbs, with little or no difference in size between the ventral and dorsal ones. This is particularly evident in embryonic feathers. Successive cross sections down the feather show the fusion of barbs to form the rhachis.

The hyporhachis is formed in the same way, the ridge nearest to the ventral point fusing with its neighbour as do the ridges near the dorsal point in forming the rhachis. The calamus is merely the cornified collar, as though the process of cornification, having gained speed in passing down the feather (correlated doubtless with the withdrawal of pulp) is here too rapid for the formation of ridges.

In view of this method of development of individual barbs, it is difficult to correlate the appearance of female bars on one side only of an otherwise symmetrical feather, with differences in growth rate of the barbs. Barbs certainly grow more quickly at their apices, where they are smaller in cross section than near the rhachis-hence the upward curve of barbs in a definitive feather. But barbs of equal length at any level must of necessity have arisen at the same time near the ventral side of the germ. Some other explanation, therefore, must be advanced for a correct interpretation of the female bar in the feathers figured (Nos. 51 and 52) by Lillie and Juhn.

A re-examination of feather development is obviously necessary for an accurate explanation of known experimental facts, and it is hoped, during the summer, to publish the results of a study, now nearing completion, of the development of nestling and definitive feathers in the domestic fowl and the duck, and of definitive feathers in the starling.

Department of Zoology, ANNE Hosker.

The University, Leeds.

1 NATURE, 133, 330, March 3, 1934

" "Physiol. Zool.,", 5, 1932.

"Morph. Jahr.", 15 ; 1899

- Bull. Mus. Comp. Zool. Harv., 40 ; 1902.

\section{Effect of Yeast Extract on the Growth of Plants}

WE have read with great interest the communication by Prof. V. Subrahmanyan and G. S. Siddappa in NATURE ${ }^{1}$ under this title, in which the authors state that in 1932-33 several Indian papers published results of their experiments, in which yeast extract was injected into plants with a marked effect on the growth and blooming. Unfortunately, we were hitherto completely unacquainted with this interesting work and, consequently, were unable to refer to it in our previous paper on the subject ${ }^{2}$.

Our work was carried out in 1932-33, and differs substantially from the observations of Subrahmanyan and Siddappa, as we showed that plants are able to take up the promoting factor (or factors) in the yeast extract, through their roots. In our opinion, this is of great interest, since it tends to show that the micro-organisms in soil are of importance in the formation of different growth-promoting factors. Soil micro-organisms would thus have functions previously unforeseen.

Further to our earlier note, we have found that the factor which stimulates the blooming of the pea is soluble in ether (communication to a meeting of the Society of Finnish Chemists on November 4 last). The extract is equally effective in sterile water cultures and in the usual pot cultures with quartz sand.

Pot cultures with different types of soil showed that in clay soil the effect of yeast extract on the growth of the pea was still distinct, although not so marked as in quartz sand. In rich humus soil the effect was very weak or possibly nil. This could be explained by assuming that the stimulating factor of yeast extract is normally present in soils rich in organic matter and with an abundant microflora.

A detailed report of our work on the subject will appear elsewhere.

Biochemical Institute,

A. I. Virtanen.

Helsingfors. Jan. 26.

SynNöve v. HAUSEN.

2 NATURE, 132, 713, Nov. 4, 1933.

a NATURE, 132, 408, Sept. 9, 1933.

\section{The Age of the Sub-Crag Implements}

I AM glad that Prof. Boswell ${ }^{1}$ has expressed an opinion upon the nature of the material attached to the surfaces of a rostrocarinate flint implement exhibited, recently, in the British Museum. There are few people for whose views upon such a matter I entertain more respect, and I intend, if he will allow me, to go further into the question of this particular implement with him, and of that of others I am in process of collecting from beneath the Red Crag. It is evident that we are dealing with a complex matter in which Prof. Boswell's specialised knowledge of Crag deposits will be of great value.

As regards the geological age of the boxstones, I find that Lankester, who made a very close study of these specimens, and, in fact, gave to them their characteristic name, states" that they are "The Remains of a Pliocene deposit, anterior to the Coralline Crag, and identified by its fossils with the Black Crag, or Diestian Sands of Belgium", while in Clement Reid's "Pliocene Deposits of Britain", p. 223, the "Sables à Isocardia Cor, or Diestian" of Belgium, are placed by him in what he calls the "Older Pliocene". Also, in the Survey Memoir "The Geology of the Country around Woodbridge, Felixstowe and Orford", p. 16, Prof. Boswell himself states : "Although the boxstone fauna has been compared with the Continental Miocene, or even with the Oligocene (Rupelian), it is at present generally regarded as of Lower Pliocene Age." It was for these reasons that, in my recent note in $\mathrm{NATURE}^{3}$, I stated that the Diestian boxstones are referable to the Lower Pliocene epoch. But, in the note mentioned, I made no ciaim that the British representatives of the Continental Diestian deposits are the boxstones of Suffolk. I merely, like Lankester, look upon the boxstones as representing, in the Suffolk Bone Bed, the Diestian Sands of Belgium.

1 NATURE, 133, 331, March 3, 1934.

J. REID MOIR.

3 NATURE, 133, 64, Jan. 13, 1934. 